\title{
HUBUNGAN PENDAPATAN KELUARGA DENGAN STATUS GIZI BALITA DI DESA KUALU WILAYAH KERJA PUSKESMAS TAMBANG KABUPATEN KAMPAR TAHUN 2018
}

\author{
Riani \\ Program Studi Profesi Ners Universitas Pahlawan Tuanku Tambusai \\ aniria22.27@gmail.com
}

\begin{abstract}
Abstrak
Konsumsi makanan merupakan salah satu faktor yang secara langsung berpengaruh terhadap status gizi seseorang terkhusus pada balita sebab kesehaan balita salah satu indikator kualitas sumber daya manusia. Gangguan gizi pada tahap ini bersifat permanen, tidak dapat dipulihkan walaupun kebutuhan gizi pada masa selanjutnya terpenuhi. Keluarga dengan kategori miskin berisiko mengalami masalah kekurangan gizi pada balita kondisi ini berefek pada rendahnya daya beli keluarga dalama memenuhi kebutuhan gizi khususnya pada balitanya. Tujuan penelitian ini adalah untuk menganalisa hubungan pendapatan keluarga dengan status gizi balita. Penelitian ini menggunakan desain cross sectional. Populasi dan sampel dalam penelitian ini 86 orang ibu yang memiliki balita dengan tehnik pengambilan sampel total sampling atau sampling jenuh. Hasil penelitian diperoleh bahwa ada hubungan pendapatan keluarga dengan status gizi balita dengan nilai $\mathrm{p}$-value 0,002. Diharapkan kepada institusi kesehatan terutama puskesmas tambang untuk meningkatkan pelayanan kesehatan dalam memberikan penyuluhan dan pelatihan kepada ibu balita khususnya tentang alternative pemenuhan kebutuhan gizi.
\end{abstract}

Kata Kunci: Pendapatan Keluarga, Status Gizi Balita

Corresponding author :

Address : Jl. Tuanku Tambusai No. 23 Bangkinang

Email : aniria22.27@gmail.com

Phone : 081268772227 
Masa anak-anak merupakan salah satu masa kehidupan yang sangat penting dan perlu perhatian seirus. Pada masa ini berlangsung proses tumbuh kembang yang sangat pesat yaitu pertumbuhan fisik dan perkembangan psikomotor, mental dan social (Wati, 2011). Masalah gizi terjadi disetiap siklus kehidupan, dimulai sejak dalam kandungan (janin), bayi, anak, dewasa, dan usia lanjut. Periode dua tahun pertama kehidupan merupakan masa penting, karena pada masa ini terjadi pertumbuhan dan perkembangan yang sangat pesat. Gangguan gizi yang terjadi pada periode ini bersifat permanen, tidak dapat dipulihkan walaupun kebutuhan gizi pada masa selanjutnya terpenuhi.

Konsumsi makanan merupakan salah satu faktor yang secara langsung berpengaruh terhadap status gizi seseorang, keluarga, dan masyarakat. Rendahnya konsumsi pangan atau kurang seimbangnya masukan zat-zat gizi dari makanan yang dikonsumsi mengakibatkan terlambatnya pertumbuhan organ dan jaringan tubuh, terjadinya penyakit, dan lemahnya daya tahan tubuh terhadap serangan penyakit serta menurunnya kemampuan kerja (Wati, 2011). Oleh karna itu, status gizi di Indonesia perlu perhatian khusus karena status gizi anak balita merupakan salah satu indikator kualitas sumber daya manusia yang menentukan tingkat kesejahteraan masyarakat, dan kualitas Sumber Daya Manusia. Untuk menunjang upaya pembangunan manusia maka perhatian terhadap kasus status gizi ditetapkan sebagai salah satu sasaran dan target Rencana Pembangunan Jangka Menengah Nasional bidang kesehatan, yaitu menurunkan prevalensi balita gizi kurang dan prevalensi balita pendek, untuk pencapaiannya telah ditetapkan 6 indikator kinerja kegiatan perbaikan gizi yang prioritas untuk dilaksanakan sebagaimana dijabarkan dalam Rencana Strategis Kementerian Kesehatan 2015-2019.

Menurut Pemantauan Status Gizi (PSG) yang dilaksanakan pada tahun 2013 dari 53.633 balita yang ditimbang terdapat 6 balita yang bergizi buruk. Pada tahun 2014 dari 53.161 balita yang ditimbang terdapat 6 orang balita gizi buruk dan semuanya mendapat perawatan. Pada tahun 2015 dari 56.581 balita yang ditimbang terdapat 6 balita yang bergizi buruk dan semuanya mendapat perawatan. Pada tahun 2016 dari 56.568 balita yang ditimbang, terdapat 11 orang balita yang bergizi buruk dan semuanya mendapat perawatan. Pada tahun 2017 dari 59.242 balita yang ditimbang, terdapat 19 orang balita yang bergizi buruk dan semuanya mendapat perawatan.

Prevalensi gizi kurang tingkat kabupaten/kota se-Provinsi Riau pada Tahun 2016 terdapat sekitar 7 kabupaten/kota dengan kasus gizi kurang dibawah target yang ditetapkan pada Renstra Dinas Kesehatan Provinsi Riau.
Kabupaten Indragiri Hilir merupakan prevalensi gizi kurang yang tertinggi yakni sebesar 10,4\% diikuti oleh Kabupaten Kampar $10 \%$ dan Kabupaten Indragiri Hulu 9,8\%, Kabupaten Rokan Hulu merupakan Kabupaten yang prevalensi gizi kurangnya paling rendah yakni $2,4 \%$ dan diikuti Kota Dumai 2,5\%, Kabupaten Pelalawan 6,\%. Kabupaten Kampar merupakan peringkat kedua persentasi dari kasus gizi kurang, data dari Dinas Kesehatan Kabupaten Kampar tercatat dari 31 puskesmas yang terdapat di Kabupaten Kampar diketahui bahwa Puskesmas Tambang penyumbang kasus gizi kurang yaitu 411 orang, kasus gizi kurang tertinggi berada di desa Kualu yaitu sebanyak 86 balita.

Permasalahan tersebut muncul sala satunya karena tingkat kehidupan masyarakat yang didominasi oleh kalangan menengah kebawah yang tentunya berpenghasilan rendah, berimbas pada daya beli masyarakat rendah akan barang kebutuhan pokok sebagai penunjang pangan dengan kandungan gizi baik, disamping ada faktorfaktor lain. Menurut penelitian Gusman (2002) dan Khair (2007) dalam Lisbet Sebataraja (2014). Masalah kekurangan gizi di Indonesia salah satunya dikarenakan dari kehidupan masyarakat Indonesia yang didominasi oleh ekonomi menengah kebawah. Keadaan demikian sangat berpengaruh pada kecukupan gizi dalam suatu keluarga. Keluarga yang masuk dalam kategori miskin, rentan terkena masalah kekurangan gizi. Hal ini dikarenakan karena rendahnya kemampuan untuk memenuhi gizi yang baik.

Peneliti dalam hal ini melakukan berbagai upaya pendekatan kepada responden untuk mengetahui secara detail perihal tingkat taraf pendapatan masyarakat khususnya desa Kualu. Hasil survey pendahuluan diketahui bahwa terdapat 16 balita dengan status gizi kurang, peneliti juga mengetahui langsung pendapatan keluarga kurang dari Rp. 3.500.000,00 dengan pengeluaran dalam sebulan Rp. 1.131.371 perkapita, dengan mata pencaharian didomiasi sebagai buruh tani, maknanya pekerjaan mereka sebagai petani tapi tidak dikebun sendiri. Dengan jumlah anggota keluarga didominasi oleh $>5$ orang. Berdasrkan permasalahan tersebut peneliti merasa perlu untuk melakukan penelitian dengan mengusung tema "hubungan pendapatan dengan status gizi balita di Desa Kualu Wilayah Kerja Puskesmas Tambang Kabupaten Kampar”.

\section{METODE}

Desain penelitian ini menggunakan desain cross sectional yaitu pengumpulan data baik variabel dependent maupun independent dilakukan dalam waktu yang sama (Notoatmodjo, 2010). Dalam hal ini peneliti bertujuan melihat "Hubungan pendapatan dengan status gizi balita. Populasi dan 
sampel merupakan responden dari ibu balita yang ada di Desa Kualu wilayah kerja puskesmas Tambang dengan jumlah 86 ibu dengan tehnik total sample atau sampling jenuh. Pengumpulan data untuk variable pendapatan diukur berdasarkan perkapita yakni kategori tidak terpenuhi jika pengeluaran responden < Rp. 1.131.371. kategori terpenuhi jika pengeluaran $\geq$ Rp. 1.131.371. Sedangkan pengumpulan data untuk variable status gizi menggunakan kuisioner dengan kategori status gizi tidak normal dengan nilai $-3 \mathrm{SD}$ s/d $<-2 \mathrm{SD}$, kategori status gizi normal jika nilai -2SD s/d 2SD. Proses selanjutnya adalah analisa data dengan analisa univariat dan bivariate, analisa bivariate dilakukan dengan menggunakan uji chi-square dengan batas kemaknaan $(<0,05)$ berarti pengujian antar variable dinyatakan ada hubungan, dan bila batas kemaknaan melampaui $(>0,05)$ berarti pengujian antar variable tersebut tidak ada hubungan (Notoatmodjo, 2010).

\section{HASIL DAN PEMBAHASAN}

\section{Analisa Univariat}

Merupakan distribusi frekuensi dari masingmasing variable yaitu :

\section{Table 1. Distribusi Frekuensi Responden Berdasarkan \\ Pendapatan Keluarga, Status Gizi di Desa Kualu \\ Wilayah Kerja Puskesmas Tambang}

\begin{tabular}{l|l|l|l}
\hline No & Variable & Frekuensi (n) & $\%$ \\
\hline 1 & Pendapatan & & \\
& Tidak terpenuhi & 61 & 70.93 \\
& terpenuhi & 25 & 29.07 \\
\hline & Total & 86 & 100 \\
\hline 2 & Status Gizi & & \\
& Tidak Normal & 51 & 59.30 \\
& Normal & 35 & 40.70 \\
\hline & Total & 86 & 100 \\
\hline
\end{tabular}

\section{Analisa Bivariat}

Merupakan analisa untuk menggambarka hubungan variable pendapatan keluarga dengan status gizi balita dengan menggunakan uji chisquare. Berikut hasil analisa bivariate tersebut :

Table 2 Hubungan pendapatan keluarga dengan status gizi balita di desa Kualu wilayah kerja puskesmas tambang

\begin{tabular}{|c|c|c|c|c|c|c|c|}
\hline \multirow{2}{*}{$\begin{array}{c}\text { Pendapatan } \\
\text { keluarga }\end{array}$} & \multicolumn{4}{|c|}{ Status gizi } & \multicolumn{2}{|c|}{ Total } & \multirow{2}{*}{$\begin{array}{c}\mathrm{pV} \\
\text { alu } \\
\mathrm{e}\end{array}$} \\
\hline & $\begin{array}{l}\text { Tdk } \\
\text { nor } \\
\text { mal }\end{array}$ & $\%$ & $\begin{array}{l}\text { Nor } \\
\text { mal }\end{array}$ & $\%$ & $\mathrm{~N}$ & $\%$ & \\
\hline $\begin{array}{l}\text { Tidak } \\
\text { terpenuhi }\end{array}$ & 35 & 68,63 & 26 & 74,29 & 61 & $\begin{array}{c}10 \\
0 \\
\end{array}$ & \multirow{2}{*}{$\begin{array}{l}0,0 \\
01\end{array}$} \\
\hline Terpenuhi & 16 & 31,37 & 9 & 25,71 & 25 & $\begin{array}{c}10 \\
0\end{array}$ & \\
\hline
\end{tabular}

\begin{tabular}{l|c|c|c|c|c|c|c|c}
\hline Jumlah & 51 & 100 & 35 & 100 & 86 & $\begin{array}{c}10 \\
0\end{array}$ & & \\
\hline
\end{tabular}

dapat diketahui bahwa dari 61 responden dengan pendapatan tidak terpenuhi, terdapat 26 balita $(74,29 \%)$ yang memiliki gizi normal. Sedangkan dari 25 responden dengan pendapatan terpenuhi, terdapat 16 balita $(31.73 \%)$ yang memiliki status gizi tidak normal. Berdasarkan uji statistik diperoleh nilai $p$ value $=0.001(p$ value $\leq 0,05)$, dengan derajat kemaknaan $(\alpha=0.05)$. Ini berarti ada hubungan pendapatan keluarga dengan status gizi balita di Desa Kulau Wilayah Kejra Puskesmas Tambang Kabupaten Kampar Tahun 2019. Dari hasil penelitian juga diketahui bahwa POR $=7.1$ hal ini berarti responden yang pendapatan tidak terpenuhi berpulang 7 kali memiliki balita mengalami status gizi tidak normal.

Tingkat pendapatan merupakan faktor yang menentukan kualitas dan kuantitas makanan yanG dikonsumsi. Kemampuan keluarga untuk membeli bahan makanan tergantung pada nesar kecilnya pendapatan, keluarga dengan pendapatan terbatas kemungkinan besar akan kurang dapat memenuhi kebutuhan makananya terutama untuk memenuhi kebutuhan zat gizi dalam tubuh (Depkes RI, 2000 : 3). Umumnya jika pendapatan naik, jumlah dan jenis makanan cenderung ikut membaik juga. Akan tetapi mutu makanan tidak selalu membaik juga kalau diterapkan tanaman perdagangan. Tanaman perdagangan menggantikan produksi pangan untuk rumah tangga dan pendapatan yang diperoleh dari tanaman perdagangan itu atau upaya peningkatan pendapatan yang lain tidak dicanangkan untuk membeli pangan atau bahanbahan pangan berkualitas gizi tinggi. Tingkat penghasilan ikut menentukan jenis pangan apa yang akan dibeli dengan adanya tambahan uang. Semakin tinggi penghasilan, semakin besar pula persentase dari penghasilan tersebut dipergunakan untuk membeli buah, sayur mayur dan berbagai jenis bahan pangan lainnya. jadi penghasilan merupakan factor penting bagi kualitas dan kuantitas .antara penghasilan dan gizi jelas ada hubungan yang menguntungkan. Pengaruh peningkatan penghasilan terhadap perbaikan kesehatan dan kondisi keluarga lain yang mengadakan interaksi dengan status gizi yang berlawanan hampir universal. Menurut penelitian Gusman (2002) dan Khair (2007) dalam Lisbet Sebataraja (2014). Masalah kekurangan gizi di PĐndonesia salah satunya dikarenakan dari kehidupan masyarakat Indonesia yang cenderung masih di bawah standar. Keadaan demikian sangat berpengaruh pada kecukupan gizi dalam suatu keluaga. Keluarga yang masuk dalam kategori 7 miskin, rentan terkena masalah kekurangan gizi. Hal ini dikarenakan karena rendahnya kemampuan untuk memenuhi gizi yang baik. Seorang ibu 
rumah tangga yang sehari-harinya terbiasa menyiapkan makanan bagi anggota keluarganya harus mempunyai pengetahuan dan ketrampilan tentang menu sehat dan gizi seimbang, sehingga makanan yang disajikan menarik untuk dikonsumsikan dan balita tidak bosan, (Sediaoetama, 2006). Keterampilan ibu sangat diperlukan dalam uapaya peningkatan status nutrisi balitanya secara baik, dalam mengatur makanan agar menjadi lebih berguna bagi tubuh, secara umum dinegara berkembang ibu memegang peranan penting dalam memilih dan mempersiapkan panagan unutk dikonsumsi keluarga (Hardiansyah, 2007)

\section{SIMPULAN}

Terdapat hubungan yang bermakna antara variable pendapatan keluarga dengan status gizi balita di desa Kualu wilayah kerja puskesmas Tambang Kabupaten Kampar tahun 2019.

\section{DAFTAR PUSTAKA}

Aeda E, (2006). Penyakit Menular dan Infeksi. Yogyakarta: Kanisius

Ambarwati R, (2015). Ilmu Gizi dan Kesehatan Reproduksi: Yogyakarta: Cakrawala Ilmu.

Amiruddin R, (2014). Determinan Kesehatan Ibu dan Anak. Jakarta: Buku Kesehatan.

Ariani P, (2017). Ilmu Gizi. Yogyakarta: Nuha Medika.

BPS Kabupaten Kampar (2017). Pengeluaran ratarata Per Kapita. Sasenas https://www.google.co.id/url?q=https://ww wbps.go.id/rata-ratapengeluaranperkapita-sebulan-menurut:kelompokbarang:2017. Di peroleh tanggal 14 Mei 2019.

Depetermen Kesehatan Republik Indonesia. Laporan Hasi Riset Kesehatan Dasar (Riskesdas). 2014.

Devi, (2010). Kecendrungan Masalah Gizi dan Tantangan di Masa Depan. Jakarta: Dirjen Kesehatan Masyarakat

Depetermen Kesehatan. Dinkes Riau (2016). Profil Kesehatan Indonesia. Tahun 2016.

Dinkes Riau (2017) Profil Kesehatan Kabupaten Kampar. Tahun 2017.

Fikawati S dkk, (2017). Gizi Anak dan Remaja. Depok: Rajawali Pers.

Hidayat A, (2007). Riset Keperawatan dan Teknik Penulisan Ilmiah. Jakarta: Salemba Medika.

Indah (2014), Hubangan Penyakit Infeksi dengan Status Gizi pada Balita di Puskesmas Jambon Kecamatan Jambon Kabupaten Ponogoro Tahun 2014, https://www.google.co.id/url?q=https://life style.kompas.com/read/201

2/01/30/13325976/Faktor.Utama.Penyeba
b.Gizi.Buruk.Anak7sa=u\&v ed. Diperoleh tanggal 12 juli 2019.

Istiono, (2009), analisis faktor-faktor yang mempengaruhi status gizi balita, jurnal kesehatan, nomor 3 halaman 5-6.

Kemenkes Republik Indonesia. Pemantauan Status Gizi (PSG). Tahun 2017.

Marinda (2010), Hubungan Pendaatan Keluarga, Pengetahuan Gizi Ibu, dan Pola Makan dengan Status Gizi Balita di Wilayah Kerja Puskesmas Sidoharjo Kabupaten Sregen,

http://www.google.co.id/urul?q=http://epri ns.ums.ac.id/24014/9/naska publlikasi.pdf\&sa=U\&ved=. Dipreroleh tanggal 11 juli 2019.

Muazlimah (2017), Hubungan Pendapatan Keluarga dengan Status Gizi Balita di Desa Ngadiluwih Kecamatan Ngadiluwih Kabupaten Kediri, https://www.google.co.id/url?=http://unpk ediri.ac.id/index.php/efektor e/article/download/965/656/7 $\mathrm{sa}=\mathrm{U} \&$ ved $=$. Diperoleh tanggal 14 juli 2019.

Notoatmodjo, (2012). Metedologi Penelitian dan Kesehatan. Jakarta: Rineka Cipta.

Nursalam, (2008). Konsep Dan Penerapan Metedologi Penelitian Ilmu Keperawatan. Jakarta: Salemba Medika.

Sri (2010), Faktor-Faktor yang Berhubungan dengan Status Gizi Balita pada Keluarga Buruh Tani di Desa Situwangi Kecamatan Rakit Kabupaten Banjarnegara Tahun 2010,

http://www.google.co.id/url=http://lib.unn es.ac.id/2880/1/3320.pdf\&s $\quad \mathrm{a}=\mathrm{U} \& \mathrm{ved}=$ diperoleh tanggal 10 juli 2019.

Sugiyono, (2017), Metode Penelitian Pendidikan. Bandung: Alfabeta. Wati, (2011), Ilmu Gizi Keperawatan dan Kesehatan. Yogyakarta: Nuha Medika 